branding, but the process is ambiguous, it includes both rise and fall. The author considers that the efficiency of innovative technologies appliance depends on a series of criteria such as flexibility, systemacity, accountability, rationality, openness and feedback.

Keywords: innovative technologies, informational technologies, marketing technologies, political image, Smart City, region

РОЗЕНБЕРГ Валерия Ивановна - аспирант кафедры российской политики факультета политологии Московского государственного университета им. М.В. Ломоносова (119991, Россия, г. Москва, Ломоносовский пр-кт, 27, корп. 4 «Шуваловский»; liorkvalery@gmail.com)

\title{
СОЦИОКУЛЬТУРНЫЕ ОСОБЕННОСТИ ПЕРЕГОВОРОВ В АРАБСКИХ СТРАНАХ
}

Аннотация. В статье рассматриваются социокультурные особенности переговоров в арабских странах. Автор подчеркивает, что в последние годы роль Ближнего Востока возросла во внешней политике не только Российской Федерации, но и всего мира. Подтверждением тому является значение сирийского конфликта на международной арене и цикл многосторонних международных переговоров и внешнеполитических изменений, которые последовали вслед за ним. По мнению автора, понимание культурных особенностей и логики арабских участников переговорных процессов может снизить конфликтность коммуникации и помочь составлению долгосрочных переговорных стратегий, что будет способствовать достижению необходимых политических соглашений.

Ключевые слова: социокультурные особенности, арабский стиль ведения переговоров, международные переговоры, внешняя политика России, национальные стили ведения переговоров

$\mathrm{B}$ последние несколько лет роль Ближнего Востока в международных отношениях резко возросла. Выгодное расположение этого региона на стыке трех континентов, его интенсивный экономический рост и общая политическая нестабильность на фоне социальных контрастов и эпизодических всплесков вооруженных конфликтов заставляют все мировое сообщество раз за разом обращать свой взгляд на него и принимать все более активное участие в многосторонних коммуникациях с его представителями. Также особое значение имеет тот факт, что Ближний Восток является одним из центров современного терроризма, что представляет огромную угрозу не только для России, но и для всего мира. По этой причине особое внимание в последнее время уделяется сирийскому конфликту: многосторонние длительные переговорные циклы стали причиной глобальных изменений в отношениях многих стран на международной арене.

При оценке сирийского конфликта некоторые аналитики характеризуют его как многослойный пирог, в который вовлечены множество противоречивых и конфликтующих интересов как отдельно взятых государств, так и блоков, группировок, играющих свою не всегда позитивную роль. В их числе, прежде всего, США и НАТО, Турция, монархии Персидского залива, главным образом Саудовская Аравия и Катар, Иран и, наконец, Россия [Ханалиев 2018: 208].

Это плотное сплетение арабских сторон еще раз акцентирует наше внимание на необходимости изучения их национальных специфических коммуникативных особенностей для эффективного представительства на современной международной арене. Если говорить об определении, то национальный стиль на переговорах можно определить как приверженность определенным культурным ценностям, традициям и обычаям, ориентацию на специфические механизмы принятия решений, а также соблюдение определенных правил поведе- 
ния во время политических переговоров, глубоко укорененных в национальной культуре [Василенко 2010: 275].

Несмотря на обширные исследования в области национальных стилей ведения переговоров, хороший специалист по переговорному процессу должен использовать знания о других культурах с большой осторожностью: необходимо избегать стереотипных и ложных суждений и помнить, что личность партнера по переговорному процессу уникальна и не может полностью соответствовать национальному портрету. Изучение основных правил арабской переговорной традиции должно помочь понять систему мышления и логику поведения восточных партнеров, что в итоге может повлиять на уровень подготовки переговорных процессов, а также на их предсказуемость и конфликтность.

Первое, что следует понять при общении с арабскими партнерами, это влияние ислама на мир бизнеса и политики. Абсолютно все должно согласовываться с его религиозными нормами и правилами. Некоторые дни и даже месяцы полностью исключаются из деловой жизни правоверного мусульманина: переговоры не проводятся во время священного месяца Рамадан, когда все мусульмане соблюдают строгий пост и посвящают свое время молитвам. Пятница также является священным днем, когда мусульмане посещают мечети для молитвы, поэтому на этот день не принято назначать приемы и встречи [Василенко 2016: 297]. Государственная власть в исламе воспринимается как нечто священное, поэтому в арабской культуре отношение к закону и властям в большинстве случаев уважительное.

Также большое значение в переговорах с арабской стороной имеет внешний вид переговорщиков, подарки, этикет, выделение титулов и должностей представителей. Арабы не допускают фамильярности, поэтому в диалоге с ними следует быть крайне аккуратными с жестикуляциями и выражениями. Невербальное общение является крайне важной составляющей диалога с арабскими представителями. Эту особенность можно заметить еще на старте деловых отношений: арабы подходят к партнерам очень близко, обмениваются визитными карточками и мягкими рукопожатиями. Жестикуляция арабов весьма отличается от жестикуляции европейцев: так, например, арабским партнерам нельзя демонстрировать ступни ног и поднимать большие пальцы рук вверх. Сами же восточные партнеры могут выражать отказ, поднимая подбородок и брови вверх, издавая цокающий звук. Невербальное общение как часть коммуникации зачастую требует отдельного внимательного изучения, поскольку обыденные в бытовом обиходе жесты могут показаться представителям других культур оскорбительными.

При разговоре о специфике арабского стиля переговоров нельзя не отметить подчиненное положение женщины в мусульманской культуре. Как правило, специалисты рекомендуют не включать представительниц женского пола в процесс переговоров с арабской стороной. Если это не представляется возможным по каким-либо причинам, женщинам рекомендуется особо внимательно отнестись к имеющимся в исламской культуре требованиям к внешнему виду [Василенко 2016: 300]:

- все части тела, кроме лица и кистей рук, должны быть закрыты;

- одежда не должна быть прозрачной и облегающей;

- одежда должна быть из категории женской одежды, а никак не мужской;

- женщина не должна пахнуть духами и другими ароматическими веществами, быть экстравагантной и вызывающей.

Арабский стиль ведения переговоров нельзя назвать быстрым. Поспешные решения выглядят для этих восточных представителей весьма подозрительными. Зачастую восточным партнерам может потребоваться некоторое время 
для обдумывания возникших вопросов - в это время партнера лучше не беспокоить, не торопиться прервать молчание и дать ему спокойно принять решение. По причине полихронности переговорам с арабскими представителями свойственны многоступенчатые стратегии с позиционными торгами, которые могут занять значительное время. Специалисты зачастую рекомендуют разработать сложную систем уступок в процессе переговоров, при этом, как правило, обмен уступками должен быть равнозначным, в ином случае достигнуть соглашения будет проблематично.

Для арабского темперамента характерны экспансивность и вспыльчивость. Зачастую на переговорах с арабами можно заметить их порывистость и несдержанность, но в скором времени эмоции затихают. В подобных переговорах нет полутонов и переходов - только прямая бескомпромиссность. По этой причине в общении с арабскими партнерами можно услышать угрозы и прямые установки: эта сторона нам враг, а эта - друг.

Профессионалы по переговорам рекомендуют оформлять все достигнутые договоренности в письменном виде, поскольку иначе принятые соглашения могут быть нарушены (особенно в условиях острых политических конфликтов).

Подводя итог, можно сказать, что арабская культура отличается ярко выраженной национальностью и во многом отличается от европейских переговорных стандартов. Все эти особенности требуют тщательной подготовки к переговорным процессам с участием арабской стороны. Учитывая тот факт, что сегодня на территории Ближнего Востока проходят наиболее ожесточенные столкновения не только за переговорными столами, но и в вооруженных конфликтах, следует обратить свое внимание на анализ логики поведения арабских партнеров. Достижение мира и понимания в общении с Востоком - это важное направление во внешней политике России, и требуются время, знания и терпение для реализации и укрепления своих интересов в этом регионе.

\section{Список литературы}

Василенко И.А. 2010. Политические переговоры. М.: ИНФРА-М. 396 с.

Василенко И.А. 2016. Переговоры с восточными партнерами: модели, стратегии, социокультурные традиции. М.: Международные отношения. 336 с.

Ханалиев Н.У. 2018. Большой Ближнний Восток. Вызовы и угрозы национальной безопасности России. М.: РИД РосНОУ. 248 с.

\section{SOCIO-CULTURAL CHARACTERISTICS OF NEGOTIATIONS IN ARAB COUNTRIES}

\footnotetext{
Abstract. The article discusses the socio-cultural characteristics of negotiations in Arab countries. The author emphasizes that in recent years, the role of the Middle East has increased in foreign policy not only of the Russian Federation, but also of the whole world. This is confirmed by the importance of the Syrian conflict in the international arena and the cycle of multilateral international negotiations and foreign policy changes, that followed it. According to the author, understanding of the cultural characteristics and logic of Arab participants in the negotiation process can reduce the communication conflict and help draw up long-term negotiation strategies that will contribute to the achievement of necessary political agreements. Keywords: sociocultural characteristics, Arabic style of negotiation, international negotiations, Russian foreign policy, national styles of negotiation
} 